\title{
https://doi.org/10.48009/1_iis_2010_689-695 \\ INFORMATION TECHNOLOGY AND DISTANCE EDUCATION
}

\author{
Manying Qiu, Virginia State University, mqiu@vsu.edu \\ Carl N. Wright, Grambling State University, wrightc@gram.edu \\ Shuting Xu, Virginia State University, sxu@vsu.edu
}

\begin{abstract}
Advances in information technologies (IT) are one of the driving forces of change in Higher Education. As colleges and universities attempt to more aggressively pursue distance education as a means in search of increasing revenue, enrollment and visibility, they must identify the current and perspective students and their needs. There have been continuous research and debate on open source learning management systems. Meanwhile the opportunities entail challenges including how to use emerging information technologies, such as Web 2.0 tools to improve online teaching and learning.
\end{abstract}

Keywords: information technology, open source software, Web 2.0.

\section{INTRODUCTION}

Advancement in information technologies (IT) is one of the major driving forces of change in organizations and society. In the fast-changing world we live, a convergence of factors such as global economy, complexity of information technologies, growing demand for sustainable competitive advantage and the emerging operations and business systems has a strong impact on higher education.

Infrastructures are growing stronger as computers double in speed while decreasing in computing and storage cost, and high-speed network connections continue to expand [13]. IT is an essential infrastructure for competitiveness of finance, manufacturing, trade, transportation, entertainment and education. IT is transforming organizations into global networked infrastructures, with processes extended all over the world, creating virtual global distributed markets and systems [5]. However, "in an economy where the only certainty is uncertainty, the one sure source of lasting competitive advantage is knowledge [17]." Knowledge is power in any society. An important aspect of education is its role as a determinant of national competitive advantage. The availability of a pool of skilled and educated workers seems to be a major determinant of the likely economic success of a country [11].

Volume XI, No. 1, 2010
In the global, technology- and knowledge-based economy, one of the impacts IT posted upon higher education is distance education. The Commission on Technology and Adult Learning [12] developed a vision for electronically delivered classes in America and viewed distance learning as having great economic benefits. The commission foresaw distance learning as a particularly strong educational method for responding to rapid changes in society and business [11].

According to U.S. Department of Education, during the 12 months of 2000-2001 academic year [21],

- 56 percent (or 2,320) of all 2-year and 4year Title IV-eligible, degree-granting institutions offered distance education courses for any level or audience, (i.e., courses designed for all types of students, including elementary and secondary, college, adult education, continuing and professional education, etc.).

- 55 percent (or 2, 280) of all institutions offered college-level, credit-granting distance education courses at either undergraduate or graduate/first-professional level.

- 48 percent (or 1,980) of all institutions offered college-level, credit-granting distance education courses at undergraduate level.

- 22 percent (or 890) of all institutions offered distance education at graduate/firstprofessional level.

(See Table 1 Below)

The authors examined 25 peer institutions of a southern regional Master's university. A peer institution is defined as "one which is representative of the target institution to which it is compared. Another name is benchmark institution." [14] A peer group is defined as "a set of peer institutions which are sufficiently similar in mission, programs, size, students, wealth, etc. to establish basic central tendencies." [14] All of the universities in the peer group offer courses online. Nine of them offer online graduate programs, while three of those nine universities offer both graduate and undergraduate programs. This paper will investigate the
Issues in Information Systems 
opportunities presented by the information technologies for traditional colleges and universities to develop distance education and the implied challenges of using information technologies to improve teaching and learning in distance education.

\section{OPPORTUNITIES}

\section{Technology and Globalization}

As colleges and universities pursue distance education in search of additional revenue, rising enrollment, increasing visibility and meeting diverse demand, they must know the answer to questions:"Who are our current and perspective students?" and "What do they want?" In recent years, market demand in information services is slowing down and demand for information security, finance, and insurance is growing stronger. Many US industries are adopting technologies, especially wireless communications at a rapid rate. Numerous users world-wide have access to wireless broadband networks via powerful handheld devices. These individuals and industrial, clinical and field based employees in particular are potential candidates for distance learning.

Information technology, especially the Internet, has created an environment that facilitates organizations to grow without geographical boundaries. The Internet has also made it possible for manufacturers, banks, investment firms, insurance companies and other organizations to deal directly with their consumers effectively and efficiently. Middlemen are finding it difficult to add enough value to warrant their markup. Retailers in almost all businesses have to compete against dot com's that have no expenses tied to equipments and facilities. When businesses moving to global market, infrastructures must be built, employees must be trained, and new skills and talents must be identified [6].

Complexity of networked distributed infrastructure, shorter product life cycles, a fast-expanding knowledge base, and the rapidly updated existing knowledge require organizations to hire new employees with IT competency and most current knowledge in the relevant areas. At the same time, employers are under tremendous pressure to upgrade worker skills in a timely, effective, economical manner, providing employees with "just in time" (JIT) training. Workers are often reluctant to interrupt their careers or give up their source of income for full-time study in traditional educational settings. Lifelong learning requires traditional colleges and universities

Volume XI, No. 1, 2010 to provide greater flexibility to accommodate diverse personal circumstances.

\section{Blended Learning}

Many on-campus students take online courses for the benefit of flexible time and reduced travel time. In 2003, the American Society for Training and Development identified blended learning as one of the top ten trends to emerge in the knowledge delivery industry. Blended learning combines online and face-to-face instruction [9]. To a large degree, the information technologies available placed constraints on the nature of the instructional methods that could be used in each environment. For example, it was not always possible to have synchronous or high fidelity interactions in the distributed environment. Because of these constraints, distributed learning environments placed emphasis on learner-material interactions, while F2F learning environments tended to place priority on the humanhuman interaction [9].

University of Houston Department of Health and Human Performance researcher finds that students in a hybrid class that incorporated distance learning with in-class lectures scored a letter grade higher on average than their counterparts who took the same class in a more traditional format [2]. In its Distance Education at Degree Granting Secondary Institutions: 2006-07 study, the National Center of Education Statistics in the US Department of Education made two major changes in the definition of distance education. First, the definition no longer included a criterion for instructional delivery to off-campus or remote locations because online courses could be accessed on campus at a convenient time and place (e.g., between classes and in a computer lab)." "Hybrid/blended online courses were defined as a combination of online and in-class instruction with reduced in-class seat time for students." [22] (See Table 2 below)

- 66 percent of the estimated 4,160 2-year and 4-year Title IV degree-granting postsecondary institutions in the nation offered any online, hybrid/blended online, or other distance education courses.

- 65 percent of the estimated 4,160 2-year and 4-year Title IV degree-granting postsecondary institutions in the nation offered college-level, credit grating online, hybrid/blended online, or other distance education courses at either (graduate and/or undergraduate) level.

Issues in Information Systems 
- 66 percent of the estimated 3,890 institutions that had undergraduate programs in 2006-07 offered college-level, creditgranting online, hybrid/blended online, or other distance education courses at undergraduate level.

- 60 percent of the estimated 1,810 institutions that offered graduate or firstprofessional programs in 2006-07 offered college-level, credit-granting college-level, credit-granting online, hybrid/blended online, or other distance education courses at graduate level.

- 23 percent of the estimated 4,160 2-year and 4-year Title IV-eligible, degree-granting postsecondary institutions in the nation offered noncredit distance education courses

Although the data in Table 1 and Table 2 are not compatible, they reflected at least two of the trends in distance education: colleges and universities are offering online courses not only off campuses but on campus as well; the adoption of hybrid/blended mode of distance education.

\section{Open Source Software}

Examining the peer institutions, the most popular offthe-shelf web-based learning management systems (LMS) being adopted is Blackboard (17 of the 25 peer institutes or $68 \%$ ). The issues of proprietary software are its unreasonable licensing prices, forced upgrades, and escalating support costs. Higher education institutions with budget constraints are very attracted to open source LMS because of their cost savings and more control. Two major open source movements are increasing their share of the education space: Sakai and Moodle [8]

The development of the Sakai Collaboration and Learning Environment (CLE) was originally funded by a grant from the Mellon Foundation as the Sakai Project (http://www.sakaiproject.org). The early versions of the software were based on existing tools created by the founding institutions, with the largest piece coming from the University of Michigan's "CHEF" course management system. Other universities originally started meeting in February 2004 including Indiana University, Massachusetts Institute of Technology, Stanford University, and Polytechnic University of Valencia are involved; and uPortal and the Open Knowledge Initiative were also represented [20].

Sakai is a community of academic institutions, commercial organizations and individuals who work together to develop a common Collaboration and Learning Environment (CLE). The Sakai CLE is a free, community source, educational software platform distributed under an open source license -the Educational Community License. The Sakai CLE is used for teaching, research and collaboration. Sakai version 1.0 was released in March 2005. As of July 2007, Sakai is in production at over 150 institutions and being piloted by over 100 more. On October 5, 2007, the University of Virginia announced that it will be implementing Sakai throughout the university [18]. One institute in the peer group, Pacific Lutheran University has also adopted Sakai.

The University of North Carolina at Chapel Hill conducted a two-year pilot evaluation of the Sakai CLE in 2007-2008. More than 1,100 people participated in the Sakai pilot during the academic year. The purpose of the pilot was to evaluate the efficacy of Sakai for teaching and learning, research, outreach and administrative work flows. Moreover, Sakai was evaluated in terms of its potential to help integrate the wide variety of tasks performed by faculty, staff, and students that advance the mission of the university into a single, unified online framework. The findings of the pilot are encouraging. All participants who responded to the Fall 2008 Exit Survey indicated that Sakai had met or exceeded their expectations. Students who participated in the pilot rated the experience favorably and were able to use Sakai to complete coursework successfully with minimal or no training in its unique features and functions. Support staff found minimal effort was required to support Sakai during this pilot period and no new staff resources were needed for the pilot [19]. Moodle (http://moodle.org) is an open source learning management system. Moodle has proven very popular in European and Latin American countries. As of May 17, 2010, Moodle has 49,481 registered, validated sites in 213 countries for 3,578, 645 courses.

Traditionally open source projects have been started and maintained by teams of volunteer programmers. More recently open source has proven its worth as a viable business model so software companies are increasingly putting payroll programmers to work on open source products. For example, both Google and Open University have put their own programmers to work on Moodle. However, the spirit of the volunteer community lives on in the form of software extensions, translations, documentation, bug reports and so on. Contributors around the world work together in order that the software evolves and improves [15]. 
By definition, open source learning management systems are collaboratively developed software that is shared with no license fees. In reality, free software is not free. Open source eliminates licensing fees and avoids being locked-in to a vender, yet customization and professional support are two of the major challenges for colleges and universities to implement open source software. The total cost of ownership of open source software is hard to calculate. The administration and support costs overshadow initial software license cost and annual maintenance fees-the costs that are minimized by open source. The lack of formal support mechanisms requires highly skilled, motivated, and creative technical personnel. Implementing a new learning management system has high entry costs because there are few efficient migration tools. Faculty members and educational technology personnel who have invested heavily in one particular system find themselves having to redo much of their work to switch to another one [3] [8].

Whether open source software is less costly to administer than proprietary software largely depends on a ready pool of resources trained on the system, the availability of administration tools that allow system administrators to manage a greater number of systems, and the number of versions and patches that are issued by the develop [3]

For the medium size peer group institutions, only one university has been using open source software Sakai; one university switched to open source software Desire2learn from Blackboard, and universities also switched from open source software (Angel) and inhouse software (courseVU) to Blackboard. (See Table 3 below)

\section{CHALLENGES}

Distance education is a planned teaching and learning experience. The non-traditional educational approach of distance learning is still at an immature stage [6]. Although some of these concepts have existed for several decades, there is not yet a clear understanding of the way these approaches will evolve and become useful and common practices [16]. Examining this peer group, there is surely but slowly substantial progress in terms of hardware, software and network availability for distance learning comparing to those in [16] ten years ago. Developing and implementing an effective distance learning and communication strategy that takes advantage of today's technologies can be challenging.

Volume XI, No. 1, 2010

\section{Faculty Issues}

As colleges and universities attempt to aggressively pursue distance education, faculty development and training is crucial. In Green's [10] survey of the role of computing and information technology in U.S. higher education, chief academic and information technology officials rated "helping faculty integrate technology into their instruction" the single most important IT issue confronting their campuses over the following two or three years. An EDUCAUSE survey supported the importance of this issue," rated the fifth overall strategic concern, as well as the fifth IT issue most likely to become even more significant in the following year [4].

\section{Student Issues}

While distance learners come from all backgrounds and walks of life, the online learners tend to be working professionals seeking to better their circumstances. They must have progressive attitudes about technology and be able to quickly adapt to technology. They must be able to quickly embrace new ideas and integrate them into their studies and their lives. Although streaming audio and video are gaining popularity in online learning, writing is still the primary means of interactive conversation. Besides commit their time and effort to distance learning, online learners need to be good writers; the quality of their writing and the ability to communicate are very much an indicator for success [23].

\section{Interactive Learning Environment}

One factor that plays a primary role in determining course quality is students' perceptions of the degree of interaction in instructional delivery. Interaction seemed to have an impact on student achievement, as well as satisfaction [18]. The biggest barrier to the success of distance education has been the difficulties of students interacting effectively with instructors, an ability inherent in the face-to-face classroom.

The information technologies that facilitate distance education evolve over the years. The most common information and communications technologies used in 1995 for distance education were two-way interactive video and one-way prerecorded video; by 1997-98, they were edge out by Internet or Webbased courses with asynchronous computer-based instruction. In the early Nineties, U.S. university students started having access to the Internet, the decentralized computer network developed during the 
Cold War that linked military and government offices with university research centers. Once the Internet was opened to the public, the use of email became so common among students and instructors that voicemail was demoted to secondary status [7].

The explosive growth of the Internet changed the essence of instructional delivery to online

learners. Distance learning no longer relies on the TV. The Internet is becoming the medium of choice for educators, since it provides all the elements vital for distance learning [6]:

- On-demand delivery of video, audio, text, and graphics.

- Immediate online access to vast libraries of research materials.

- Real-time or near-real-time interaction among instructors and students.

Yet the Internet has disadvantages when compared to television. It takes time to download a low-resolution video clip while TV can deliver a full program in living color. The latest trend has been to create "multiple media" distance learning systems, using curricula from both the

television and computer [7].

In Europe, University College Dublin constructed interactive classroom facility under their

"Blueprint for Interactive Classrooms" (BIC). UCD built an interactive classroom for teaching

distant learners through various audiovisual technologies, including the Internet, video

conferencing and interactive television $[1,7]$. The top examples in North America are the advanced teacher training centers built by TCI in Denver and Washington DC. Each classroom

has an interoperable PC or Mac on every desktop, linked to a big screen in front of the room.

Teachers can display on the main screen whatever they choose from whatever source they

choose, be that source their computer, a student's computer, the World Wide Web, digital video stored on a server, or any program from a pay TV channel [7]. Both the TCI and the BIC

classrooms were equipped with robotic cameras so activities in that space may be shared with

students sitting in remote classrooms or their homes. These were classrooms without walls.

Now we have moved from the Internet era of Web 1.0 - Course/Learning Management Systems - to the Internet era of Web 2.0, which is about communication, collaboration and knowledge construction. Web 2.0 refers to those online services that allow the end-user to create or add content to the web. The examples include blogs, wikis, flickr, twitter, youtube, and many, many others. The Web 2.0 services/tools made it easy for anyone with no special computer skills to create/share content online.

A special sub-set of Web 2.0 is Social Media or Social Networking tools. These tools typically do have some sort of content creation/sharing capability but the more important function they have is the ability to decide WHO you will share with and under what context. These types of services may also have online status indicators letting people know when you're online or available to interact in some way.

A main concern with distance education has always been its lack of $\mathrm{f} 2 \mathrm{f}$ interaction. Distance learners may feel challenged when it comes to real life communication and presentation. Communicating via Web 2.0 social media or social networking can ease the issue to some extent, but not entirely.

\section{CONCLUSION}

Advances in information and communications technology is one of the driving forces of change.

The fast changing society is demanding a change in Higher Education. There are tremendous opportunities and needs for distance education, but the opportunities imply challenges to developing online programs and use information technologies to improve teaching and learning. Diversified sources of students demand various format of instructional delivery. Is open source course/learning management systems truly cost effective? It is important to help faculty and students master information technologies and communication skills. Although IT has evolved into Web 2.0 Internet era, interaction between faculty and distance learners still has room to be improved.

\section{REFERENCES}

[1] BiC Blueprint for Interactive Classrooms (2002) http://bic.avnet.kuleuven.be/index.html

[2] Campus Technology (2008) University of Houston Study: Hybrid Courses More Effective for Students (April 8th) http://www.campustechnology.com/articles/60481

[3 ] Computer Economics (2005) Key Advantage of Open Source Is Not Cost Savings

[4] Crawford, G., Rudy, J. A., \& the EDUCAUSE Current Issues Committee. (2003). Fourth 
annual EDUCAUSE survey identifies current IT issues, November. Pp.12-26.

[5] Cunha, M. M. and D.P Goran. (2007) "A changed economy with unchanged universities? A contribution to the university of the future," International Journal of Distance Education Technologies (Oct-Dec).

[6] Finch, B.J (2008) Operations Now: Supply Chain Profitability and Performanc,3/e, New

York NY: McGraw Hill.

[7] Freed, K. A History of Distance Learning: Interactive Distance Learning http://www.media-visions.com/ed-distlrn1.html

[ 8 ] Ganjalizadeh, Saiid and Pablo Molina (2006). Overview of Open Source Learning Management Systems. http://net.educause.edu/ir/library/pdf/DEC0602.pdf

[9] Graham, Charles R. (2004). "Blended Learning Systems: Definition, Current Trends, and Future Directions"

http://www.publicationshare.com/graham_intro.pdf

[10] Green, K. C. (2002). Campus Computing 2002: The 13th national survey of computing and information technology in American higher education. Encino, CA: Campus Computing.

[11] Hill, Charles, W.L. (2008). Global Business Today 6/e, New York NY: McGraw Hill.

[12] Hodgins, H. Wayne, (2000). Into the Future A Vision Paper for American Society for Training and Development (ASTD) and National Governors' Association.

[13] Howell, S.L., P.B. Williams and N.K. Lindsay (2003). "Thirty-two Trends Affecting Distance Education: An Informed Foundation for Strategic Planning," Online Journal of Distance Learning Administration, Vol.VI, No. 3, Fall)

[14] Ingram, J.H. (1995) "Using IPEDS Data for Selecting Peer Institutions," AIR Annual Forum Paper.

[15] Kineo O pen Source Open source learning management systems: a primer http://www.kineoopensource.com/index.php/freeresources/insights/Open-source-learning$\underline{\text { management-systems.html }}$
[16] Lau, L and Qiu, M (1998). "Distance Learning: Is It Worth It?" co-authored with L. Lau. The Society for Advancement of Management 1998 International Conference, April, Washington, D.C.

[17] Newman, B. "Agents, Artifacts, and Transformations: the Foundations of Knowledge Flows," The Knowledge Management Handbook, C. Holsapple, ed. Springer-Verlag, 2002.

[18] Roblyer, M.D. (2000). How Interactive are YOUR Distance Courses? A Rubric for

Assessing Interaction in Distance Learning, Online Journal of Distance Learning

Administration, Vol. III, No.2I.

[19] The University of North Carolina at Chapel Hill (2009) Sakai Pilot Evaluation

Final

Report http://www.unc.edu/sakaipilot/evaluation/FinalReptOct15-09-sm.pdf

[20] Unicon http://www.unicon.net/opensource/sakai

[21] National Center for Education Statistics (2003). Distance

Education at Degree-Granting Postsecondary Institutions: 2000-2001 (NCES 2003-017). http://nces.ed.gov/pubs2003/2003017.pdf

[22] National Center of Education Statistics (2008) Distance Education at Degree Granting Secondary Institutions: 2006-07 First Look http://nces.ed.gov/pubs2009/2009044.pdf

[23] Virtualstudent.com Profile of Students Seeking Online Degrees http://www.virtualstudent.com/html/profile.html 


\section{TABLES}

Table1. Total number of 2-year and 4-year Title IV degree grating institutions, and the number and percent Of institutions that offered distance education courses, by level of institutional offering: 2000-01

\begin{tabular}{|c|c|c|c|c|c|c|c|c|c|}
\hline \multirow{3}{*}{$\begin{array}{l}\text { Level of instructional } \\
\text { offerings }\end{array}$} & \multirow{3}{*}{$\begin{array}{r}\text { Total } \\
\text { number } \\
\text { of } \\
\text { institutio } \\
\text { ns }\end{array}$} & \multirow{2}{*}{\multicolumn{2}{|c|}{$\begin{array}{l}\text { Offered any } \\
\text { distance } \\
\text { education } \\
\text { courses }\end{array}$}} & \multicolumn{6}{|c|}{$\begin{array}{l}\text { Offered college-level. Credit-granting distance } \\
\text { education courses }\end{array}$} \\
\hline & & & & \multicolumn{2}{|c|}{$\begin{array}{c}\text { Courses at either } \\
\text { level }\end{array}$} & \multicolumn{2}{|c|}{$\begin{array}{r}\text { Undergraduate } \\
\text { courses }\end{array}$} & \multicolumn{2}{|c|}{$\begin{array}{r}\text { Graduate/first- } \\
\text { professional } \\
\text { courses }\end{array}$} \\
\hline & & $\begin{array}{c}\text { Numbe } \\
\mathrm{r}\end{array}$ & $\begin{array}{c}\text { Percen } \\
\mathrm{t}\end{array}$ & $\begin{array}{c}\text { Numbe } \\
\mathrm{r}\end{array}$ & Percent & $\begin{array}{c}\text { Numbe } \\
\mathrm{r}\end{array}$ & $\begin{array}{c}\text { Perce } \\
\text { nt }\end{array}$ & $\begin{array}{c}\text { Numb } \\
\text { er }\end{array}$ & $\begin{array}{c}\text { Perce } \\
\text { nt }\end{array}$ \\
\hline $\begin{array}{c}\text { All } \\
\text { institutions,,,,,,,,,,,,,, }\end{array}$ & 4,130 & 2,320 & 56 & 2,280 & 55 & $1,98-$ & 48 & 890 & 22 \\
\hline $\begin{array}{l}\text { Institutions with } \\
\text { undergraduate }\end{array}$ & 3,810 & 2,170 & 57 & 2,150 & 57 & 1,980 & 52 & 760 & 20 \\
\hline $\begin{array}{l}\text { Programs } \ldots \ldots \ldots \ldots \ldots \\
\ldots \ldots\end{array}$ & & & & & & & & & \\
\hline $\begin{array}{l}\text { Institutions with } \\
\text { graduate/first- } \\
\text { Professional } \\
\text { programs......... }\end{array}$ & 1,700 & 1,080 & 63 & 1,050 & 62 & 750 & 44 & 880 & 52 \\
\hline
\end{tabular}

SOURCE: [21, Table 3]

Table2. Total number of 2-year and 4-year Title IV degree grating postsecondary institutions, and percent of institutions that offered distance education courses, by course type, institutional type, and institution size : 2006-07

\begin{tabular}{|c|c|c|c|c|c|c|}
\hline \multirow[b]{2}{*}{ Institutional type and size } & \multirow[b]{2}{*}{$\begin{array}{r}\text { Total } \\
\text { number of } \\
\text { institutions }\end{array}$} & \multirow{2}{*}{$\begin{array}{r}\text { Percent } \\
\text { offered any } \\
\text { online, } \\
\text { hybrid/blended } \\
\text { online, or } \\
\text { other distance } \\
\text { education } \\
\text { courses }\end{array}$} & \multicolumn{3}{|c|}{$\begin{array}{l}\text { Percent offered college-level, credit-granting online, } \\
\text { Hybrid/blended online, or other distance education courses }\end{array}$} & \multirow{2}{*}{$\begin{array}{r}\text { Percent } \\
\text { offered } \\
\text { noncredit } \\
\text { distance } \\
\text { education } \\
\text { courses }\end{array}$} \\
\hline & & & $\begin{array}{r}\text { Courses at } \\
\text { either level }\end{array}$ & $\begin{array}{r}\text { Undergraduate } \\
\text { courses }\end{array}$ & $\begin{array}{r}\text { Graduate/ } \\
\text { First-professional } \\
\text { courses }\end{array}$ & \\
\hline All institutions.......... & 4,200 & 66 & 65 & 66 & 60 & 23 \\
\hline \multicolumn{7}{|l|}{ Institutional type } \\
\hline Public 2-year............... & 1,000 & 97 & 97 & 97 & $\mathrm{n} / \mathrm{a}$ & 50 \\
\hline Private for-profit 2-year...... & 500 & 18 & 16 & 16 & $\mathrm{n} / \mathrm{a}$ & $\mathrm{n} / \mathrm{a}$ \\
\hline Public 4-year................. & 600 & 89 & 88 & 87 & 82 & 42 \\
\hline Private not-for-profit 4-year. & 1,500 & 53 & 53 & 51 & 46 & 40 \\
\hline Private for-profit 4-year...... & 300 & 70 & 70 & 70 & $\mathrm{n} / \mathrm{a}$ & $\mathrm{n} / \mathrm{a}$ \\
\hline \multicolumn{7}{|l|}{ Size of institution } \\
\hline Less than $3,000 \ldots \ldots \ldots \ldots$ & 2,700 & 51 & 51 & 51 & 44 & 11 \\
\hline 3,000 to $9,999 \ldots \ldots \ldots \ldots \ldots . .$. & 900 & 91 & 91 & 88 & 77 & 42 \\
\hline 10,000 or more $\ldots \ldots \ldots \ldots \ldots$ & 500 & 97 & 96 & 93 & 90 & 53 \\
\hline
\end{tabular}

Table 3. Peer institutions' Course Management Systems

\begin{tabular}{|l|l|l|l|l|l|l|l|}
\hline & \multicolumn{2}{|c|}{ Commercial CMS } & \multicolumn{3}{c|}{ Open Source } & inHourse \\
\hline & Blackboard & WebCT & Sakai & Angel & Desire2learn & Sherpa & courseVU \\
\hline 2008 & 14 & 4 & 1 & 3 & 1 & 1 & 1 \\
\hline 2010 & 17 & 2 & 1 & 2 & 2 & 1 & 0 \\
\hline Switches & Bb $\rightarrow$ Desire2learn 1 & WebCT $\rightarrow$ Bb 2 & ANGEL $\rightarrow$ Bb 1 & courseVU $\rightarrow$ Bb 1 & & & \\
& & & & & & \\
\hline
\end{tabular}


